\title{
The First Record of Embolemidae (Hymenoptera Chrysidoidea) in the Rovno Amber (Upper Eocene) of Ukraine: A Male of Ampulicomorpha succinalis Brues
}

\author{
M. Olmi ${ }^{a}$, A. P. Rasnitsyn ${ }^{b}$, and A. Guglielmino ${ }^{a}$ \\ ${ }^{a}$ Department of Plant Protection, University of Tuscia, Viterbo, Italy \\ e-mail: olmi@unitus.it \\ ${ }^{b}$ Borissiak Paleontological Institute, Russian Academy of Sciences, Profsoyuznaya ul. 123, Moscow, 117997 Russia \\ e-mail: rasna36@yahoo.com \\ Natural History Museum, London, SW7 5BD England \\ Received January 11, 2010
}

\begin{abstract}
A male of Ampulicomorpha succinalis Brues (Hymenoptera Chrysidoidea: Embolemidae) from the Upper Eocene Rovno amber (34-37 Ma) is described for the first time.
\end{abstract}

Keywords: Hymenoptera, Embolemidae, Rovno amber, Eocene, Ukraine.

DOI: $10.1134 / \mathrm{S} 0031030111010138$

\section{INTRODUCTION}

Fossil Embolemidae (Hymenoptera Chrysidoidea) are known not only from amber (Rasnitsyn and Matveev, 1989; Olmi, 1995; Brothers and Rasnitsyn, 2003), but also as rock fossils (Rasnitsyn, 1975, 1996; Olmi et al., 2010). The following fossil species of this family have been recorded: Early Cretaceous: the Baissa locality (Russia, Transbaikalia, Siberia; Berriasian, Zaza Formation): Baissobius minimus Rasnitsyn, 1996; B. parvus Rasnitsyn, 1975; B. minutus Olmi, Rasnitsyn et Guglielmino, 2010; Embolemopsis baissensis Olmi, Rasnitsyn et Guglielmino, 2010; and the Bon Tsagan locality (Mongolia; Aptian, Khurilt beds): Baissobius carolianus Rasnitsyn, 1996; Late Eocene, Baltic amber: Ampulicomorpha succinalis Brues, 1933; Embolemus breviscapus Brues, 1933. In addition, an undescribed embolemid specimen has been found in lake deposits of the Turonian Orapa locality in Botswana, southern Africa (Brothers and Rasnitsyn, 2003). One more specimen has recently been recorded in Late Eocene Rovno amber (Ukraine); it is described in the present study.

\section{MATERIAL AND METHODS}

The Rovno amber is considered to be roughly contemporaneous with the Upper Eocene Baltic amber but originated from a different source area (Ukrainian Shield), as the composition of the arthropod inclusions witnesses (see Perkovsky et al., 2007; Dlussky and Rasnitsyn, 2009 for details).

The description below follows the terminology used by Olmi (1984, 1994, 1999). The measurements reported are relative, except for the total length (head to abdominal tip, without the antennae). In the descriptions, POL is the distance between the inner edges of the two lateral ocelli; OL is the distance between the inner edges of a lateral ocellus and the median ocellus; OOL is the distance from the outer edge of a lateral ocellus to the compound eye; OPL is the distance from the posterior edge of a lateral ocellus to the occipital carina; TL is the distance from the posterior edge of the eye to the occipital carina. It was impossible to obtain POL, OL, OOL, and OPL,

The material studied is housed in the Schmalhausen Institute of Zoology of the National Academy of Sciences of Ukraine, Kiev, Ukraine (SIZK).

\section{SYSTEMATIC PALEONTOLOGY}

Family Embolemidae Förster, 1856

Genus Ampulicomorpha Ashmead, 1893

Ampulicomorpha succinalis Brues, 1933

Plate 13, figs. 1-3

Ampulicimorpha [sic!] succinalis: Brues, 1933, p. 114.

Ampulicomorpha succinalis: Rasnitsyn and Matveev, 1989, text-figs. 2-4; Olmi, 1995, p. 267, text-fig. 7, 2; 1996, p. 98.

H o 1 o t y p e has been lost (Rasnitsyn and Matveev, 1989).

De s c ription. Male; fully winged; apparently black, except palpi, which are brown, and browntestaceous gaster. The antennae are filiform, not geniculated, not thickened distally, apparently without rhinaria; the antennal segments show the following proportions: $12: 4: 35: 28: 26: 24: 22: 22: 19: 20$; the antennae are articulated with strong frontal pro- 


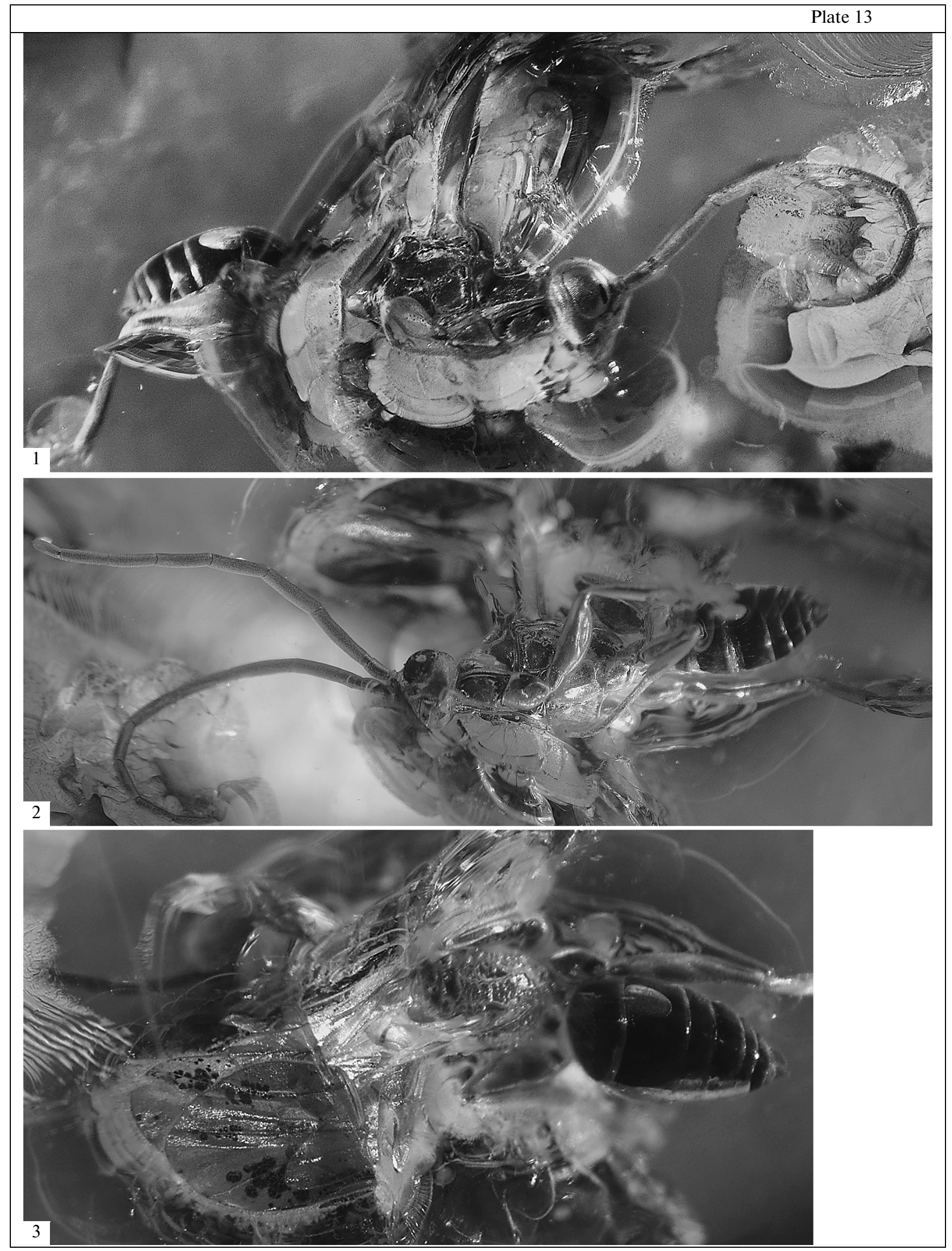

PALEONTOLOGICAL JOURNAL Vol. $45 \quad$ No. 12011 
cesses; the distance from the antennal sockets to the clypeus is very large. The head is apparently dull and granulated, with a swollen dorsal side; the frontal line is apparently absent; the occipital carina is complete; the ocelli are distinct; POL, OL, OOL, OPL not measurable because the ocelli are only seen in lateral view. TL is shorter than the eye (10:14); eyes are large, approximately half as long as the head $(14: 29)$ in dorsal view; the region of frons from the clypeus to antennal toruli are only partly visible; the mandibles are partly visible, but the teeth are invisible. The pronotum is only seen in lateral view, with a dull, granulated lateral regions; the pronotal tubercles reach the tegulae. The scutum, notauli, scutellum, and metanotum are invisible. The propodeum is completely reticulate rugose, with very large areolae; the dorsal surface is sculptured by two irregular median longitudinal keels (the area between these keels is reticulate rugose). The propodeum is much shorter than the gaster $(36: 83)$ and much longer than the petiole $(36: 5)$. The forewing is fully developed, apparently completely darkened; the marginal cell is open; the distal part of the stigmal vein is longer than the proximal part $(25: 20)$; 1 SDC and 1 DC cells ( $1 \mathrm{mcu}$ and 2 cua cells after Rasnitsyn, 1980, $1 \mathrm{M}$ and $2 \mathrm{Cu}$ after Huber and Sharkey, 1993) are completely enclosed by pigmented veins. The hind wing is partly visible. The forelegs show the following proportions of segments: 20 (coxa) : 8 (trochanter) : 39 (femur) : 32 (tibia) : 20 (tarsal segment 1) : 5 (tarsal segment 2) : 5 (tarsal segment 3$): 6$ (tarsal segment 4) :5 (tarsal segment 5). The midlegs are in the following proportions: 20 (coxa) : 5 (trochanter) : 33 (femur) : 35 (tibia) : 21 (tarsal segment 1$): 7$ (tarsal segment 2) : 6 (tarsal segment 3) : 5 (tarsal segment 4) :7 (tarsal segment 5). The hind legs are in the following proportions: 22 (coxa) : 8 (trochanter) : 49 (femur) : 50 (tibia) : 25 (tarsal segment 1) : 9 (tarsal segment 2) : 9 (tarsal segment 3) : 6 (tarsal segment 4) : 6 (tarsal segment 5). The tibial spurs formula is $1,2,2$.

M e a s u r e m e n ts, mm: body length, 5.0.

$\mathrm{R} \mathrm{e} \mathrm{m}$ a r k s. Ampulicomorpha succinalis is the only known fossil species of Ampulicomorpha (Olmi, 1996). It was described based on a female specimen (originally identified as "male?") and another specimen not further specified, both in Baltic amber. The types were stored in the amber collection of the Albertus University in Konigsberg (=Kaliningrad) and have to be regarded as lost, according to Rasnitsyn and Matveev (1989). There is a defective female specimen at the Borissiak Paleontological Institute of the Russian Academy of Sciences, Moscow (Russia). It was drawn by Rasnitsyn and Matveev (1989) and described by Olmi (1995). In 2009, the third female specimen was found in the Jurgen Velten's amber collection, Idstein,
Germany (unpublished data). In the same 2009, a male specimen was discovered for the first time in the Rovno amber described herein. This is the first embolemid discovered in the Rovno amber.

The presence of the Baltic species Ampulicomorpha succinalis in the Rovno amber (Ukraine) is not surprising, since their arthropod assemblages are similar in composition even if far from identical because of similar age and only moderately distant source areas of ambers (for more detail, see Perkovsky et al., 2007; Dlussky and Rasnitsyn, 2009). In particular, species of Dolichopodidae (Diptera), Kalotermitidae (Isoptera), Coniopterygidae, and Nevrorthidae (Neuroptera) have been identified in common between the Rovno and Baltic ambers (Kupryjanowicz and Makarkin, 2008; Makarkin and Perkovsky, 2009). In addition, $74 \%$ of ant species and all 6 species of Psocoptera recorded in the Rovno amber were previously described from the Baltic amber (Kupryjanowicz and Makarkin, 2008; Dlussky and Rasnitsyn, 2009). The Rovno amber is chemically identical with the Baltic amber and both are considered to be roughly contemporaneous, Late Eocene (Perkovsky et al., 2007).

Achterberg and Kats (2000) considered Ampulicomorpha Ashmead, 1893 and Embolemus Westwood, 1833 as synonyms. In actual fact, there are sometimes many difficulties to attribute a male specimen to Ampulicomorpha or Embolemus, because the length and pigmentation of the veins enclosing the 1SDC cell (and mostly the posterior spurious vein near the 1A vein) are sometimes variable (1SDC being either closed or open is the only character used for separating males of the two above genera; the females are not a problem, because they are apterous or micropterous in Embolemus and macropterous in Ampulicomorpha). However, we prefer to continue to consider both genera as valid, because in the majority of cases, there are no difficulties to recognize the two genera. As recognized by the Achterberg and Kats (2000: 254) themselves, probably "certainty about this problem will be gained after a thorough analysis of both sexes of the species involved, preferably including DNA analysis."

M a t e r i a 1. SIZK K-1973 from the Klesov locality.

\section{ACKNOWLEDGMENTS}

The authors appreciate help rendered by E.E. Perkovsky (Schmalhausen Institute of Zoology, National Academy of Sciences of Ukraine, Kiev) for making the specimen available for study, and for consultations.

\section{Explanation of Plate 13}

Figs. 1-3. Male of Ampulicomorpha succinalis Brues, SIZK K-1973, Upper Eocene Rovno amber (Ukraine): (1) right side, $\times 19$; (2) left and below, $\times 16.5$; (3) upper view, $\times 21.5$. 


\section{REFERENCES}

1. C. van Achterberg and R. J. M. van Kats, "Revision of the Palaearctic Embolemidae (Hymenoptera)," Zool. Med. Leiden, No. 74, 251-269 (2000).

2. D. J. Brothers and A. P. Rasnitsyn, "Diversity of Hymenoptera and Other Insects in the Late Cretaceous (Turonian) Deposits at Orapa, Botswana: A Preliminary Review,” Afr. Entomol. 11 (2), 221-226 (2003).

3. C. T. Brues, "The Parasitic Hymenoptera of the Baltic Amber: Part I," in Bernstein-forschungen (Amber Studies), Ed. by K. Andree (De Gruyter, Berlin und Leipzig, 1933), Vol. 3, pp. 4-178.

4. G. M. Dlussky and A. P. Rasnitsyn, "Ants (Insecta: Vespida: Formicidae) in the Upper Eocene Amber of Central and Eastern Europe," Paleontol. J. 43 (9), 1024-1042 (2009).

5. M. S. Engel and E. E. Perkovsky, "An Eocene Bee in Rovno Amber, Ukraine (Hymenoptera, Megachilidae)," Am. Mus. Novit., No. 3506, 1-11 (2006).

6. J. Huber and M. J. Sharkey, "Structure," in Hymenoptera of the World, Ed. by $\mathrm{H}$. Goulet and J. Huber (Agrical. Canada, Ottawa, 1993), pp. 13-59.

7. J. Kupryjanowicz and V. N. Makarkin, "Archiconiocompsa prisca Enderlein (Neuroptera: Coniopterygidae): The First Neuropteran Fossil in Rovno Amber (Ukraine)," Entomol. Fen. 19, 25-31 (2008).

8. M. Olmi, "A Revision of the Dryinidae (Hymenoptera)," Mem. Am. Entomol. Inst. 37, 1-1913 (1984).

9. V. N. Makarkin and E. E. Perkovsky, "Rophalis relicta Hagen (Neuroptera, Nevrorthidae) in the Late Eocene Rovno Amber, with a Discussion of the Taxonomic Status of the Genus," Denisia 26, 137-144 (2009).
10. M. Olmi, "The Dryinidae and Embolemidae (Hymenoptera: Chrysidoidea) of Fennoscandia and Denmark," in Fauna Entomologica Scandinavica (E.J. Brill, Leiden, 1994), Vol. 30, pp. 1-100.

11. M. Olmi, "Dryinids and Embolemids in Amber (Hymenoptera: Dryinidae et Embolemidae)," Redia 78, 253-271 (1995).

12. M. Olmi, "A Revision of the World Embolemidae (Hymenoptera Chrysidoidea)," Frust. Entomol. (1995), N. S., 18 (31), 85-146 (1996).

13. M. Olmi, "Hymenoptera Dryinidae_Embolemidae," in Fauna d'Italia (Edizioni Calderini, Bologna, 1999), Vol. 37, pp. 1-425.

14. M. Olmi, A. P. Rasnitsyn and A. Guglielmino, "A Revision of Rock Fossils of Dryinidae and Embolemidae (Hymenoptera Chrysidoidea)", Zootaxa 2499, 21-38 (2010).

15. E. E. Perkovsky, A. P. Rasnitsyn, A. P. Vlaskin and M. V. Taraschuk, "A Comparative Analysis of the Baltic and Rovno Amber Arthropod Faunas: Representative Samples," Afr. Invertebr. 47, 229-245 (2007).

16. A. P. Rasnitsyn, "Hymenoptera Apocrita of the Mesozoic," Tr. Paleontol. Inst. Akad. Nauk SSSR 147, 1-134 (1975).

17. A. P. Rasnitsyn, "Origin and Evolution of Hymenoptera," Tr. Paleontol. Inst. Akad. Nauk SSSR 174, 1-192 (1980).

18. A. P. Rasnitsyn, "New Early Cretaceous Embolemidae (Vespida = Hymenoptera: Chrysidoidea)," Mem. Entomol. Soc. Washington 17, 183-187 (1996).

19. A. P. Rasnitsyn and D. G. Matveev, "The First Palearctic Representative of the Genus Ampulicomorpha Ashmead," Entomol. Obozr. 68, 657-661 (1989). 